\title{
Performance Value of Services in Service Organizations in Applying One-Stop Integrated Services
}

\author{
$1^{\text {st }}$ Fino Wahyudi Abdul ${ }^{1}, 2^{\text {nd }}$ Wahidin Septa Zahran ${ }^{2}, 3^{\text {rd }}$ Diana Prihadini ${ }^{3}, 4^{\text {th }}$ Dony \\ Hendrartho ${ }^{4}$ \\ \{fino@stiami.ac.id ${ }^{1}$ \}
}

Departement of Logistic Management, Faculty of Social Science and Management, Institut Ilmu Sosial dan Manajemen STIAMI, Jakarta, Indonesia ${ }^{1}$, Departement of Business Administration, Faculty of Administrastion Science, Institut Ilmu Sosial dan Manajemen STIAMI, Jakarta, Indonesia ${ }^{2,3,4}$

\begin{abstract}
One-stop integrated services have been implemented in Indonesia in less than twenty years. The application of one-stop integrated services in Indonesia is very necessary to improve and accelerate the process of licensing services in several major cities in Indonesia. But in its implementation there has not been much measurement of the performance of integrated services. On this basis, this study seeks to measure the value of an integrated service performance index (IKP), the purpose of which is to get an overview of service performance in the form of a service performance index. Lean approach method and measurement using integrated service performance index (IKP) are used to obtain the speed of the licensing process and the measure of service performance index. Data collection techniques carried out are literature studies and field observations, with processing and data analysis methods using a lean approach and 7 types of waste (7 waste). The final results obtained are integrated service performance index (IKP) values which are then analyzed by indicators that have a low value potential factor which results in a low integrated service performance index in a one-stop integrated service organization. The one-stop integrated service organization that was observed was the Service Department Technical Unit (UPTD) one-stop integrated service (PTSP), Koja sub-district, North Jakarta municipality, DKI Jakarta.
\end{abstract}

Keywords: Integrated Service Performance Index, Lean, 7 Waste, One-Stop Integrated Service.

\section{Introduction}

Complex licensing procedures in Indonesia are a problem for the general public, including the people of Jakarta and surrounding areas, complicated and long-standing procedures are one of the problems. In this era of millennia and digital economy, acceleration and increase in productivity are not only needed in the field of production or manufacturing, but also in services and services, so that the results of this study are expected to provide an overview of service performance to customers or the public. There is not much literature that provides an overview of public service performance, although Halik (2014), in his study stated that the reason for conducting research is that there are no indicators to measure performance on 
standard PTSP, so that the research is carried out through the perspective of key performance indicators in provide assessment of service performance in PTSP organizations.

In a study conducted by Furterer and Elshennawy (2005), the lean method can be applied to services in local government, such as those applied in several states of the United States. In the study, the implementation of the lean method turned out to be able to increase the speed of service time to the public and improve the effectiveness and efficiency of public service organizations in several states of the United States. In addition, the repair process is carried out to provide an increase in the quality of public services by eliminating unnecessary processes or activities that result in waste of time and service costs.

Lean application is how to define activities that have added value and those that are not value added, then eliminate these non-value-added values, by using systematic procedures to change the work environment so that it produces speed in work(Chen \& Cox, 2012). Lean service with lean thinking can be effectively applied in the service industry to cut costs from activities that are not valuable and increase customer satisfaction (Bonaccorsi, Carmignani, \& Zammori, 2011; Chen \& Cox, 2012). In addition, lean can be defined as a systemic approach to identifying and eliminating waste, facilitating the flow of material, products and information with continuous improvement (Gaspersz, 2007). Liker (2006) explains that in the Toyota Production System (TPS) there are seven types of waste (7 waste) that do not add value, namely overproduction, waiting (over waiting time), transportation (too much transfer), overprocessing (excess in doing work processes), inventory (too much in storing goods), motion (too much unnecessary movement) and defect (too many defects in service or defect production).

The public service sector in the city of Jakarta is one sector that has an important role in driving the city's economy. Good quality public services will create competitiveness. One form of service quality is how to serve the community / customers with good speed and timeliness. This study aims to analyze service performance in service organizations to obtain the level of effectiveness of public services after the implementation of one-stop integrated services.

Service to customers or the general public is an important activity that must be maintained the quality of service. The form of service quality is photographed in the performance of services carried out by service providers to customers or the general public. Problems that arise can come from responses from customers to the quality of service they get, such as speed and timeliness in serving customers. In addition, licensing procedures that are too long, long and complex are a problem that must be faced by the people in Indonesia, including in the city of Jakarta. One of the goals applied by PTSP is to obtain efficiency in service time and reduce any unnecessary activities.

In 2007, the Asian Foundation instituted a study which resulted in an integrated service performance index (IKP). Integrated service performance index (IKP) is the value of service performance based on several dimensions and the results are used to measure the capacity and performance of each integrated service organization, using service index dimensions, which consist of structure, operations, licensing processes, perceptions of service users and volume issuance of permits (Goldberg, 2007). According to (Nakhai \& Neves, 2009) and (Pires de Souza et al., 2013) in some countries service is one of the sectors that affect the economy of a country and responses and complaints from customers are always the focus that is handled comprehensively.

The analysis used to measure service performance is used the Integrated Service Performance Index (IKP) approach method while to measure the efficiency and effectiveness of services used the lean method approach. Integrated Service Performance Index Analysis is 
used to measure the value of organizational performance in integrated services, while the lean method is used as an approach in achieving efficiency and effectiveness.

The dimensions in measuring the Integrated Service Performance Index (IKP) are structure, operations, licensing processes, and perceptions of service users. Then the scores are determined based on the definition of each indicator in each dimension, which will show the value of service performance in the form of a service performance index. To get optimal efficiency and effectiveness, an analysis of the lean management approach is carried out so that the expected performance can be achieved, then the analysis process is continued with a diffine and measurement approach.

According to Goldberg (2007), the management of a "One Stop Shop" (OSS) business license, also known as integrated service, is faster and cheaper licensing by integrating the management of various types of licensing into an integrated service. Services like this help increase the number of new formal entrepreneurs, then significantly increase the amount of regional income and of course strong economic growth will be achieved.

\section{Research Methods}

In this study, there are three stages used to discuss it, namely define, measurement and analyze. The first step is define, which defines the problems that arise by looking for critical to quality which is a potential factor, the search for problems is done with a lean approach to one-stop integrated services (PTSP). The second stage is measurement, which measures the performance of PTSP organizations by using an integrated service performance index (IKP) (Goldberg, 2007). The third stage is analyze, which is analyzing the potential factors obtained in the first stage.

The lean approach is used in the first stage to get the root potential problem factor, the tools used are 7 waste consisting of overproduction, waiting, transportation, overprocessing, inventory, motion and defect. In addition, a lean approach with 7 wastes is used to obtain efficiency and effectiveness in a one-stop integrated service organization (PTSP), and from seven types of waste, namely inventory that has the potential to be wasteful, because there are too many documents needed in licensing, this become a potential factor that must be addressed.

The instrument used in collecting data was checking the interview contents that were asked, and employees in the One Stop Integrated Service agency were used as informants in this study. The type of data used in this study is quantitative data based on the service dimensions category, the sample dimensions of the service index. While the analytical method used is a quantitative method based on numerical data on the dimensions of the service index, which is processed by calculating percentages and measuring scales, while literature studies and field observations are used for collecting research data. Literature studies were conducted to see the discussions conducted by other researchers related to PTSP service performance, while observations were made to collect servant performance index data (Goldberg, 2007) in the field through informants in PTSP organizations. The research location is in the UPTD PTSP in Koja District, North Jakarta Municipality, DKI Jakarta. 


\section{Result and Discussion}

Based on the results of observations, the data obtained through PTSP UPTD staff informants in Koja District, North Jakarta are shown in Table 1. The data in Table 1. are the results of integrated service performance index (IKP) measurements in accordance with the references of The Asian Foundation (Goldberg, 2007).

Table 1. PTSP service performance index, Koja District

\begin{tabular}{ccc}
\hline Dimension & Value & $\begin{array}{c}\text { Maximum score that can be } \\
\text { achieved }\end{array}$ \\
\hline Structure & 130 & 170 \\
\hline Operations & 50 & 250 \\
\hline Licensing process & 144 & 100 \\
\hline Perception of service users & 61,25 & 600 \\
\hline Total & 385,25 & \\
\hline
\end{tabular}

Source : Research result 2018

\subsection{Difine stage}

At this stage, define, which defines the problems that arise by looking for potential factors, defining the problem is done with a lean approach to one-stop integrated services (PTSP). In Table 1 , there are 2 potential factors that can be problematic, firstly the excessive licensing process passed by the community in applying for overprocessing, in the PTSP UPTD organization in Koja sub-district, North Jakarta Municipality, DKI Jakarta. The PTSP UPTD of Koja Sub-District does not handle the permit process for IMB, TDI and HD / SITU, the licensing process is handled at the North Jakarta Municipal Office.

The second number of documents required and required (inventory) in processing permits in PTSP organizations in Koja sub-district, North Jakarta Municipality, which exceeds 12 documents. So that the type of waste on 7 waste that has the potential as a potential factor is waiting and inventory, because the waiting time is too long and the required document requirements are too much, in the management of permits that must be handled.

\subsection{Measurement stage}

At this stage an integrated service performance index (IKP) was measured at the UPTD PTSP in Koja District. It can be seen that the total service performance index (IKP) integrated in Table 1 is 385.25 of the total maximum index value of 600 which can be obtained, according to the maximum measurement reference from the Asian Foundation. This shows that the integrated IKP value in the PTSP UPTD in Koja sub-district, North Jakarta is still far from the maximum value. Why this happens, in Table 1, first on the dimensions of the structure, and the licensing process, there are several indicators that are not handled directly or 
not the authority of the PTSP UPTD in Koja Subdistrict, but rather through a higher level, namely the North Jakarta Municipal Office.

Secondly there are several indicators on the dimensions of the licensing process, namely the time of the document administrator that is more than 15 days and there are still quite large different indicators between the targeted time for completing documents with the time spent by customers or the community. Third, in the dimensions of the licensing process there are still indications related to the required document requirements, the requirements required exceed 12 documents.

Fourth, in the dimension of perceptions of service users, it does not have a compliance officer, which functions as an office space specifically dealing with components from the community. The five costs are still expensive in measuring the integrated service performance index. Table 2 shows the values of the indicators of each dimension compared to the maximum value that can be achieved by these indicators, in the PTSP UPTD of Koja Subdistrict, from Table 2 the potential factor is in the dimensions of the licensing process and structure.

\begin{tabular}{|c|c|c|}
\hline Dimension & Indicator & $\begin{array}{r}\text { Value achieved=Reason The maximum value } \\
\text { that can be achieved }\end{array}$ \\
\hline Structure & $\begin{array}{l}\text { Handle IMB, TDI and } \\
\mathrm{HD} / \text { SITU permissions }\end{array}$ & $\begin{array}{l}0=\text { Does not directly } 3 \text { permits } \times 10=30 \\
\text { handle IMB, TDI and } \\
\mathrm{HD} / \text { SITU permissions }\end{array}$ \\
\hline \multirow[t]{3}{*}{ Licensing process } & $\begin{array}{l}\text { Many documents } \\
\text { needed to take care of } \\
\text { IMB, TDI and HD / } \\
\text { SITU }\end{array}$ & $\begin{array}{l}0=\text { more than } 123 \text { licenses } \times 6=18 \\
\text { documents }\end{array}$ \\
\hline & $\begin{array}{l}\text { Time for managing TDI } \\
\text { and HD SITU } \\
\text { documents }\end{array}$ & $\begin{array}{l}4=\text { Time needed } 2 \text { licensing } \times 6=12 \\
\text { between } 16-30 \text { days }\end{array}$ \\
\hline & $\begin{array}{l}\text { Official fees needed to } \\
\text { arrange IMB permits }\end{array}$ & $\begin{array}{l}0=\text { It costs more than } 6 \\
\text { Rp. } 1,875,225\end{array}$ \\
\hline $\begin{array}{l}\text { Perception of service } \\
\text { users }\end{array}$ & $\begin{array}{l}\text { Does it havea } \\
\text { compliance officer? }\end{array}$ & $\begin{array}{l}0=\text { No compliance } 5 \\
\text { officer }\end{array}$ \\
\hline
\end{tabular}

Table 2. Comparison of integrated service performance index values

Source : Research result 2018

\subsection{Tahap Analyze stage}

The measurement results in Table 1 and the measurement phase, found the root problem in the service performance index value, namely in the process of licensing and structure. The root of this problem is based on analysis using the Pareto diagram model. The dimensional values in Table 1 are converted into an assessment diagram (Pareto diagram) as in Figure 1 and Figure 2, the Pareto diagram is based on Pareto analysis. 
Bass (2007), Pareto analysis is a very simple analysis. This analysis is based on the principle that 80 percent of problems are found at the root of 20 percent of the causes of the problem.

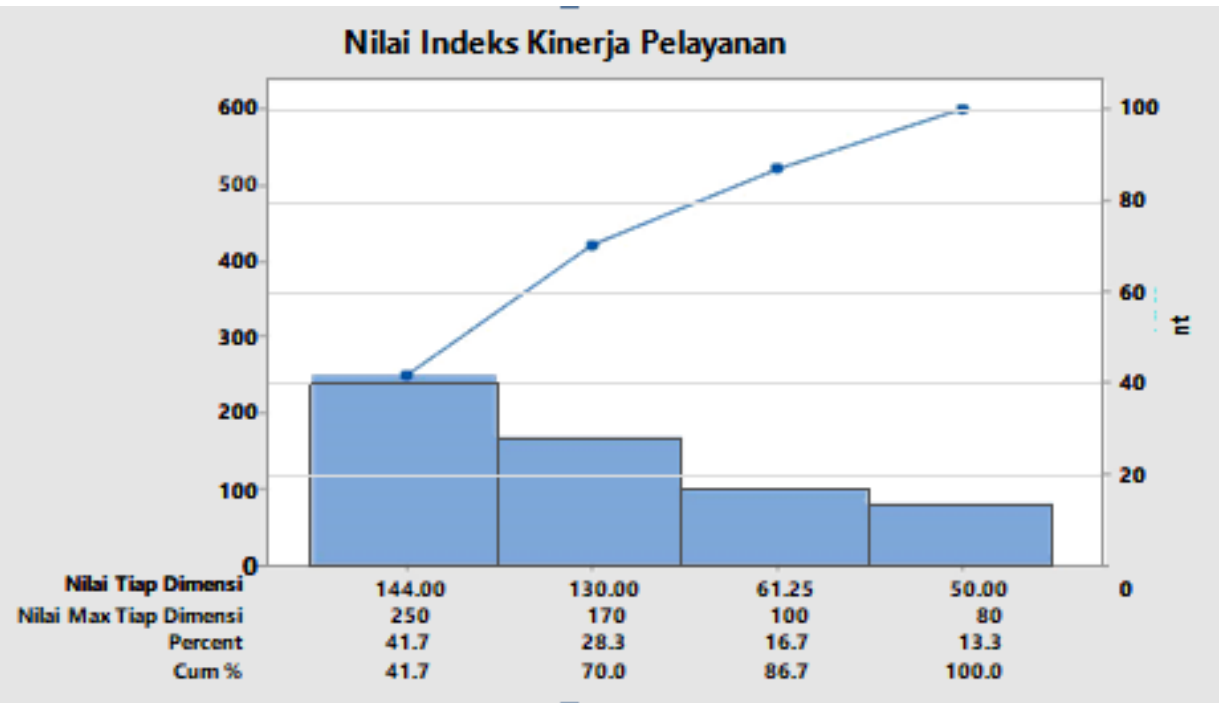

Figure 1. Service performance index value based on the maximum value of each dimension that can be achieved

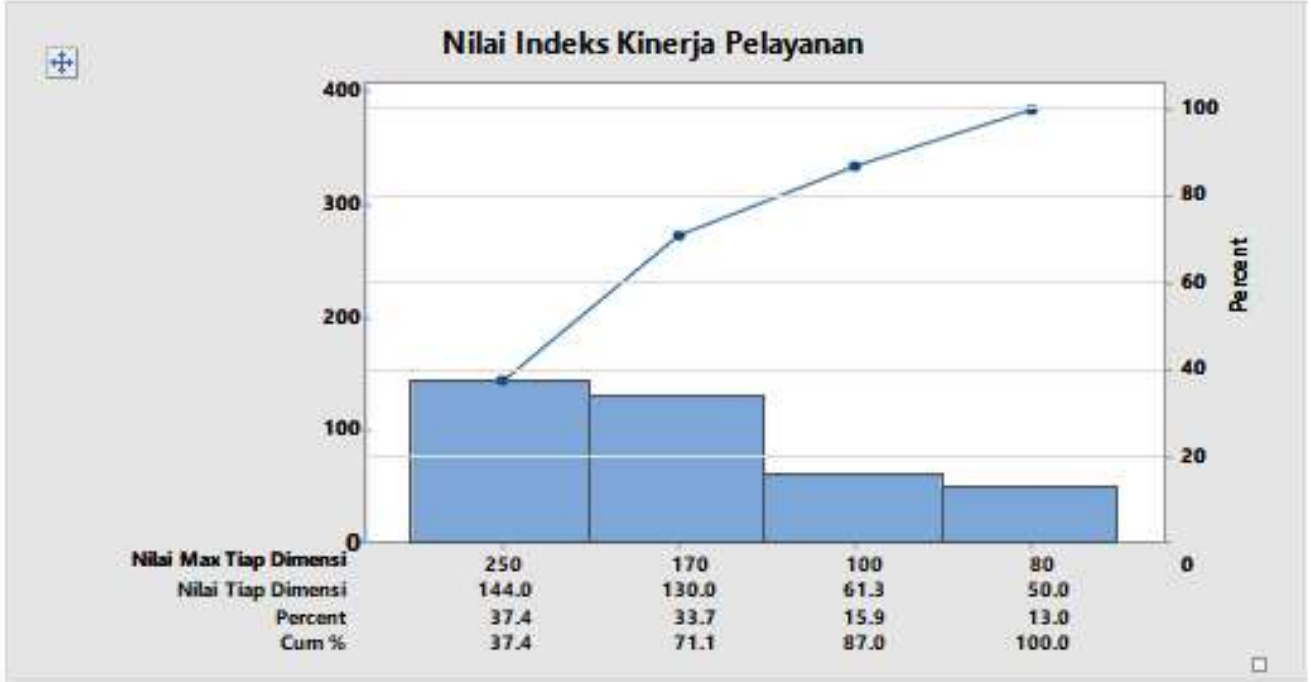

Figure 2. Nilai indeks kinerja pelayanan berdasarkan nilai tiap dimensi yang dicapai

The values obtained from Figure 1 and Figure 2 show that the dimensions of the licensing process and structure have a service performance index value that affects the service performance index value in another dimension. Nearly $80 \%$ of the service performance index value is owned by the licensing process dimension (250 for maximum values and 144 for achieved values) and structure (170 for maximum values and 130 for achieved values) and only a range of $20 \%$ service performance index values owned by dimension of perception of 
service users (100 for maximum values and 61.25 for achieved values) and operational (80 for maximal values and 50 for those achieved).

\section{Conclusion}

Based on the results and discussion, it can be concluded that this research is first, the description of the performance of integrated one-door services can be measured based on an integrated service performance index (IKP), by measuring the dimensions of structure, operations, licensing processes and perceptions of service users. From the value of the measured results obtained from these dimensions, the service performance index value in PTSP organizations can be known.

Second, the integrated service performance index (IKP) value at the one-door integrated service UPTD in Koja sub-district, North Jakarta municipality, DKI Jakarta has not yet reached its maximum value or can be said to be far from the maximum integrated service performance index.

Based on the conclusions obtained, then one solution to improving the value of service performance is the implementation of the lean method with a 7 waste approach to be able to improve the service performance index value in poor dimensions, so that it can increase the integrated service performance index value. This approach can help integrated service organizations or doors (PTSP) reduce the accumulation of time, unnecessary costs and the number of documents needed.

\section{Acknowledgement}

Finally, there is no saying that can be conveyed, except to thank the presence of God Almighty and our thanks to Mr. Dr. Panji Hendraso, Mr. Yulianto, Mr. Dr. Hartono, Ms. Yana Kalapadang, colleagues at the LPPM Institut Ilmu Sosial and Manajemen Stiami and colleagues who cannot be mentioned one by one. For the encouragement $\&$ assistance that has been given to us to complete this research.

\section{References}

[1]. Bass, I. (2007). Six Sigma Statistics with Excel and Minitab. 1st ed., New York, The McGraw-Hill Companies, Inc.

[2]. Bonaccorsi, A., Carmignani, G., \& Zammori, F. (2011). Service Value Stream Management ( SVSM ): Developing Lean Thinking in the Service Industry. Journal of Service Science and Management, 4, 428-439. https://doi.org/10.4236/jssm.2011.44048

[3]. Chen, J. C., \& Cox, R. A. (2012). Value Stream Management for Lean Office-A Case Study. American Journal of Industrial and Business Management, 02(02), 17-29. https://doi.org/10.4236/ajibm.2012.22004

[4]. Furterer, S., \& Elshennawy, A. K. (2005). Implementation of TQM and Lean Six Sigma Tools in Local Government: a Framework and a Case Study. Total Quality Management \& Business Excellence, 16(10), 1179-1191. https://doi.org/10.1080/14783360500236379

[5]. Gaspersz, V. (2007). Lean Six Sigma for Manufacturing and Service Industries. Cetakan Keempat, Jakarta, PT. Grademia Pustaka Utama. 
[6]. Goldberg, M. (2007). Mengukur Kinerja Pelayanan Terpadu untuk Perizinan Usaha di Indonesia. The Asian Foundation.

[7]. Halik, A. (2014). Kajian Pengembangan Kebijakan Pelayanan Terpadu Satu Pintu (Ptsp) Melalui Perspektif Indikator Kinerja Utama (Iku). Bina Praja, 6(1), 1-18. https://doi.org/10.21787/jbp.06.2014.41-50

[8]. Liker, J., K. (2006). The Toyota Way 14 Prinsip Manajemen dari Perusahaan Manufaktur Terhebat di Dunia, Jakarta, Penerbit Erlangga.

[9]. Nakhai, B., \& Neves, J. S. (2009). The challenges of six sigma in improving service quality. International Journal of Quality \& Reliability Management, 26(7), 663-684. https://doi.org/10.1108/02656710910975741

[10].Pires de Souza, R., Hékis, H. R., Oliveira, L. A. B., Queiroz, J. V., Queiroz, F. C. B. P., \& Valentim, R. A. D. M. (2013). Implementation of a Six Sigma project in a 3M division of Brazil. The International Journal of Quality \& Reliability Management, 30(2), 129-141. https://doi.org/http://dx.doi.org/10.1108/02656711311293553 